\title{
Two- and three-dimensional gravity modeling along western continental margin and intraplate Narmada-Tapti rifts: Its relevance to Deccan flood basalt volcanism
}

\author{
Somdev Bhattacharji ${ }^{1}$, Rajesh Sharma $^{1}$ and Nilanjan Chatterjee ${ }^{2}$ \\ ${ }^{1}$ Department of Geology, Brooklyn College and Graduate Center of the City University of New York, \\ Brooklyn, New York 11210, U.S.A. \\ ${ }^{2}$ Department of Earth, Atmospheric and Planetary Sciences, Room 54-1216, \\ Massachusetts Institute of Technology, Cambridge, Massachusetts 02139, U.S.A.
}

The western continental margin and the intraplate Narmada-Tapti rifts are primarily covered by Deccan flood basalts. Three-dimensional gravity modeling of +70 mgal Bouguer gravity highs extending in the north-south direction along the western continental margin rift indicates the presence of a subsurface high density, mafic-ultramafic type, elongated, roughly ellipsoidal body. It is approximately $12.0 \pm 1.2 \mathrm{~km}$ thick with its upper surface at an approximate depth of $6.0 \pm 0.6 \mathrm{~km}$, and its average density is $2935 \mathrm{~kg} / \mathrm{m}^{3}$. Calculated dimension of the high density body in the upper crust is $300 \pm 30 \mathrm{~km}$ in length and $25 \pm 2.5$ to $40 \pm 4 \mathrm{~km}$ in width. Three-dimensional gravity modeling of +10 mgal to -30 mgal Bouguer gravity highs along the intraplate Narmada-Tapti rift indicates the presence of eight small isolated high density mafic bodies with an average density of $2961 \mathrm{~kg} / \mathrm{m}^{3}$. These mafic bodies are convex upward and their top surface is estimated at an average depth of $6.5 \pm 0.6$ (between 6 and $8 \mathrm{~km}$ ). These isolated mafic bodies have an average length of $23.8 \pm 2.4 \mathrm{~km}$ and width of $15.9 \pm 1.5 \mathrm{~km}$. Estimated average thickness of these mafic bodies is $12.4 \pm 1.2 \mathrm{~km}$. The difference in shape, length and width of these high density mafic bodies along the western continental margin and the intraplate Narmada-Tapti rifts suggests that the migration and concentration of high density magma in the upper lithosphere was much more dominant along the western continental margin rift. Based on the three-dimensional gravity modeling, it is conjectured that the emplacement of large, ellipsoidal high density mafic bodies along the western continental margin and small, isolated mafic bodies along the Narmada-Tapti rift are related to lineamentreactivation and subsequent rifting due to interaction of hot mantle plume with the lithospheric weaknesses (lineaments) along the path of Indian plate motion over the Réunion hotspot. Mafic bodies formed in the upper lithosphere as magma chambers along the western continental margin and the intraplate Narmada-Tapti rifts at estimated depths between 6 and $8 \mathrm{~km}$ from the surface (consistent with geological, petrological and geochemical models) appear to be the major reservoirs for Deccan flood basalt volcanism at approximately $65 \mathrm{Ma}$.

\section{Introduction}

The Deccan flood basalts on the Indian lithosphere are associated with three major tectonic features: western continental margin, intraplate NarmadaTapti and Cambay rifts (figure 1). The western continental margin rift extends in N-S direction and is bounded by a prominent normal fault on the eastern side along the west coast of India. However, the western boundary is not well defined as the faults are buried by Tertiary sediments in the Arabian Sea. The intraplate Narmada-Tapti rift

Keywords. Gravity modeling; Bouguer gravity; rift; Deccan volcanism. 
extends in E-W to ENE-WSW direction and is delineated by high angle $\left(65^{\circ}-70^{\circ}\right)$ northward dipping normal faults of the Tapti rift on the southern side and southward dipping Narmada step-like listric normal faults (Bhattacharji et al 1996) of the Narmada rift zone. The width of the intraplate Narmada-Tapti rift ranges from $30-40 \mathrm{~km}$ at the western end to about $120 \mathrm{~km}$ in the east. The rift is cut by transverse tear faults at certain intervals throughout its entire length. Numerous hot springs are present along the major transverse faults. The faults of the intraplate Narmada-Tapti rift have been known to be seismically active from historic times to as recent as 1997 (U.S. Geological Survey 1997). The Cambay rift paralleling the western continental margin rift extends from latitude $21^{\circ}$ to almost $25^{\circ} \mathrm{N}$ and longitude $71^{\circ} 30^{\prime}$ to $73^{\circ} 45^{\prime} \mathrm{E}$ in NNW-SSE direction. The western and eastern margins of Cambay rift are also bounded by step normal faults. Throughout its entire length the Cambay rift is dissected in several major crustal blocks by steeply dipping faults. At the southern most part of Cambay rift and the northern most part of the western continental margin rift the Moho is at a shallow depth of about $18 \mathrm{~km}$ (Kaila 1988).

The western and central parts of the peninsular Indian lithosphere are demarcated by complex patterns of gravity anomalies owing to lateral variations in density at different depths (Thakur et al 1993). Kailasam et al (1972) provided detailed regional gravity studies of Deccan Trap areas of peninsular India. Qureshy $(1971,1981)$ analyzed the regional tectonics of western and central India from the Bouguer gravity anomaly map of the Indian sub-continent and concluded that the central part of the Narmada-Tapti rift represents a horst type structure (figure 1). He also suggested that the horst blocks may be related to an increase in density of the crust through incorporation of material from the upper mantle into the crust. A more recent two-dimensional (2-D) analysis of Bouguer gravity anomalies combined with deep seismic sounding (DSS) profiles of Kaila (1988) in Narmada-Tapti region revealed a $15-20 \mathrm{~km}$ thick high density $\left(3020 \mathrm{~kg} / \mathrm{m}^{3}\right)$ igneous layer at the base of the crust (Singh 1998). On the basis of regional Bouguer gravity anomalies and air-borne magnetic anomalies, Mishra (1977) first suggested a possible extension of the Narmada-Tapti rift on the peninsular Indian lithosphere crossing the western continental margin and the Cambay Bay towards the Arabian Sea. According to Bhattacharya and Subramanyam (1986), magnetic measurements also indicate that the normal faults at the continental margin off Saurashtra conform to the northern boundary faults of the Narmada rift graben. More recently, Pant et al (1999) reevaluated the gravity and seismic data and concluded that the crust across the Narmada-Tapti rift can be divided into upper (2-12 km depth), middle (12-25 km depth) and lower $(25-40 \mathrm{~km})$ sections. These authors proposed that while the upper crust is granitic, the lower crust may be composed of a high density "underplated" material.

The rest of peninsular India covered by the Deccan Traps is characterized by negative gravity anomalies (from $-10 \mathrm{mgal}$ to $-110 \mathrm{mgal}$ ). The lowest gravity anomaly of $-110 \mathrm{mgal}$ is encountered around $17^{\circ} \mathrm{N}$ and $74^{\circ} \mathrm{E}$. An important feature of the Bouguer gravity anomaly pattern from the west coast to the central part of peninsular India is the presence of a number of gravity "highs" and "lows" in sequence (Nayak 1990). Kailasam et al (1972) originally suggested that these anomalies are not related to the various thicknesses of high density Deccan basalts. They interpreted the "lows" as a manifestation of the sedimentary basins underneath the Deccan Traps and the gravity "highs" along the western continental margin and in peninsular central India represent prominent deep-seated structural features underneath the Deccan Traps. West of the western continental margin these structural features are largely submerged under the sea-floor of the Arabian Sea.

In a series of papers on DSS studies of central peninsular India (especially the Narmada-Tapti rift region and the western continental margin) Kaila and his co-workers (Kaila et al 1981, 1985, 1989; Kaila and Rao 1985; Kaila and Krishna 1992) suggested deep crustal structures mostly covered by the Deccan Traps. Kaila (1988) also presented a detailed gravity anomaly map for the western continental margin and over the Narmada-Tapti region of central India based on a compilation of gravity anomaly maps of India (Takin 1966; National Geophysical Research Institute 1978 and other sources). For this study we have used Kaila's Bouguer gravity map, and the gravity anomaly data for the Narmada-Tapti region of central India collected under the CRUMANSONATA project of the Geological Survey of India and used by Nayak (1990) and Verma and Banerjee (1992) for gravity anomaly maps. For this study, we have digitized these Bouguer gravity data and present a modified gravity anomaly map (figure 2). A prominent feature of this map is a positive anomaly of +70 mgal near Bombay (Mumbai) extending in an N-S direction from Bombay (Mumbai) to Surat along the western continental margin of India (figure 2). Takin (1966) interpreted this gravity high as a result of a subsurface high density body, but no relationship was found between the thickness of the Deccan basalts and the gravity high. Kaila (1988) explained this gravity high in terms of a transitional crust of very thin granitic layer underlain by 


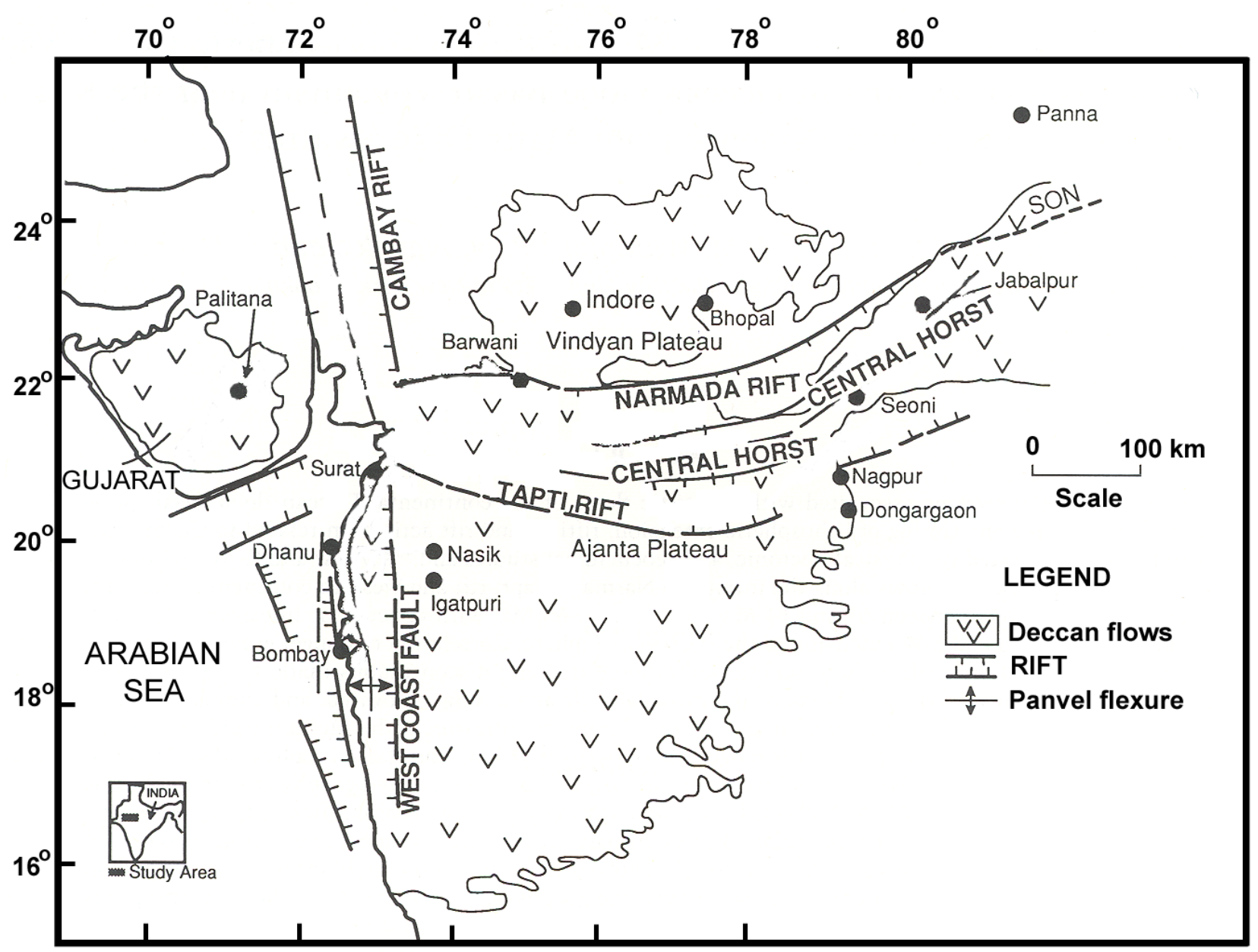

Figure 1. Tectonic map of western and central parts of peninsular India showing the western continental margin, the Narmada-Tapti and the Cambay rifts (modified after Bhattacharji et al 1996). Only the prominent normal faults along the western continental margin and Narmada-Tapti rifts are shown.

a thick basaltic layer. However, the specific depth and density contrast between the granitic and the basaltic layers and their theoretical gravitational effects were not considered in his study.

Negi et al (1992) used the technique of spectral analyses for the gravity data and concluded that the gravity high at the western continental margin of India indicates the presence of two subsurface structures at depths of $4.5 \pm 0.5 \mathrm{~km}$ and $18 \pm 2 \mathrm{~km}$, respectively. These subsurface features represent the basement and the upwarped Moho. Using an initial depth of $17.7 \mathrm{~km}$ and a density contrast of $430 \mathrm{~kg} / \mathrm{m}^{3}$ between this high gravity structure and the surrounding lower crust, Negi et al (1992) suggested that this gravity high represents a conduit or a pipe-like funnel-shaped structure. They also argued that this conduit was the locus for the main Deccan basalt eruptions. They attributed this funnel-shaped structure to be the site of a large bolide impact at the Cretaceous/ Tertiary boundary. Recently, Bhattacharji et al (1996) have shown from geochemical, petrological and geochronological studies that the tholeiitic dikes along the western continental margin and the intraplate Narmada-Tapti rifts over these gravity highs served as primary feeders from crustal magma reservoirs to the main Deccan basaltic flows.

In recent years, there have been several important studies on 2-D analyses of Bouguer gravity anomalies and tectonic modeling based on seismic (Mishra 1992) and seismic cum gravity anomaly studies of the Narmada-Tapti region (Singh and Meissner 1995; Singh 1998, 2002; Tewari et al 2001; Radhakrishna et al 2002). Singh (1998) also presented a three-dimensional (3-D) density model of the accreted igneous layer at the base of the crust beneath the Narmada-Tapti region.

The main objective of the present study is to establish 3-D gravity models along the western continental margin and the intraplate Narmada-Tapti rifts in order to confirm the $3-\mathrm{D}$ shape of high density mafic bodies, and the subsurface depths of their top surfaces. The other purpose of the present 


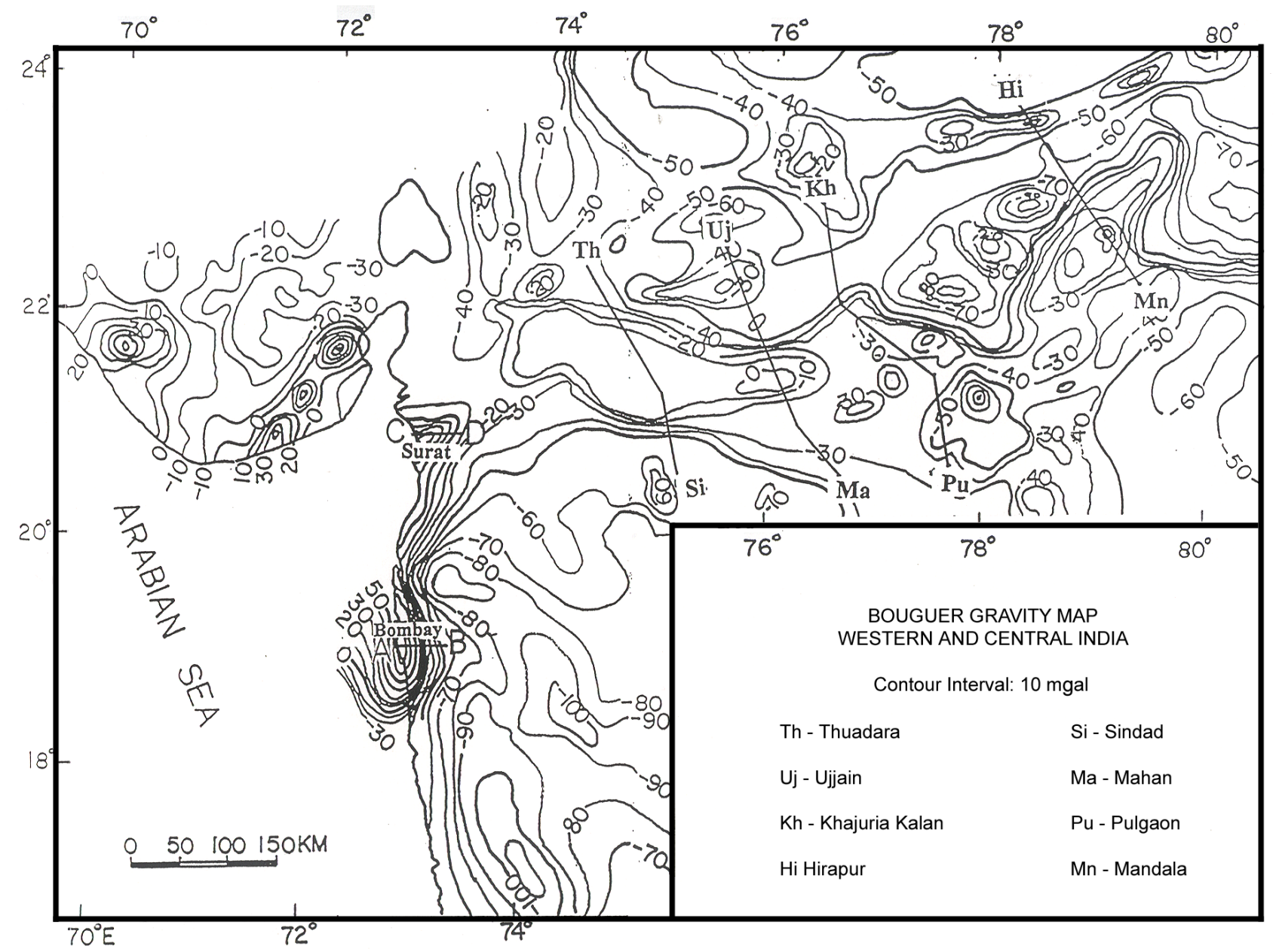

Figure 2. Bouguer gravity map of western India and the Narmada-Tapti rift area used in this study. The western margin of India is marked by maximum positive gravity highs of +70 mgal near Bombay (Mumbai). Locations of four DSS Profiles of Kaila (1988) along the Narmada-Tapti rift are also shown. 2-D gravity models along A-B near Bombay (Mumbai) and C-D near Surat, and along four DSS profiles over the Narmada-Tapti rift are shown in figures 3 and 5 , respectively.

study is to explore the possibility that these high density bodies were roots to the voluminous and copious eruptions of Deccan basalts along the lineaments and rifts when India was stationed over the Réunion hotspot.

\section{Methodology: Two and three- dimensional gravity modeling}

The depth and mass of the mafic bodies responsible for the gravity highs along the western continental margin and Narmada-Tapti rifts are estimated using the method of Garcia-Abdeslem (1995). According to Sharma (1986) the amplitude of a gravity anomaly is an index of the depth of the mafic body. The depth of a body can be estimated from a given gravity anomaly by considering a regular sphere, horizontal cylinder or slab shape for a geological body (Sharma and Bhattacharji 1996).
Smith $(1959,1960)$ has provided maximum depthestimation formulae for local gravity and magnetic anomalies, which are independent of the shape of the anomalous mass. These are based on $\Delta g_{\max }$ and $\Delta g^{\prime}$, the maximum gravity anomaly value and its horizontal gradient. The depth $Z_{g}$ to the top of the body can be expressed as

$$
Z_{g} \leq 0.86\left|\Delta g_{\max } / \Delta g^{\prime}\right|
$$

When the magnitude of anomaly is only partly known, the gravity value at a point $\Delta g(x)$ and its horizontal gradient $\Delta g^{\prime}(x)$, can be used to calculate the depth by using the equation

$$
Z_{g} \leq 1.5\left|\Delta g(x) / \Delta g^{\prime}(x)\right| .
$$

For bodies elongated in one direction the numerical factor may be replaced by 0.65 in equation 1 and by 1.0 in equation 2 .

In this study we have used the methods of Garcia-Abdeslem (1995) for the inversion of gravity 
data in order to construct 3-D shape of subsurface bodies along the western continental margin and the Narmada-Tapti rifts. Garcia-Abdeslem (1995) has solved the forward problem in wavenumber domain in which the gravity anomaly power spectrum is given by the product of functions, such as the density, depth, thickness and the horizontal dimensions (width and length) of the subsurface body. The representation of this power spectrum $g(k)$ is given by the function

$$
\begin{aligned}
g(k) & =\operatorname{Ln} \frac{1}{2 \pi} \int_{0}^{2 \pi} \mathrm{d} \theta|\Delta g(k, \theta)|^{2} \\
& =C+H(k, h)+T(k, t)+S(k, a, b),
\end{aligned}
$$

where

$$
\begin{aligned}
C & =2 \operatorname{Ln}(2 \pi G \rho), \\
H(k, h) & =-2 h k, \\
T(k, t) & =2 \operatorname{Ln}\left\{k^{-1}\left(1-e^{-k t}\right)\right\}
\end{aligned}
$$

and

$$
S(k, a, b)=\operatorname{Ln} \frac{1}{2 \pi} \int_{0}^{2 \pi} \mathrm{d} \theta|s(k, \theta)|^{2},
$$

$H(k, h), T(k, t)$ and $S(k, a, b)$ are the depth, thickness and horizontal dimension (length and width) functions, respectively. Here, $a$ and $b$ are the length and width of the body, $t$ is thickness (the difference in the top and bottom surfaces of the body), and $h$ is depth to the top surface of the body. $G$ is the gravitational constant and $\rho$ is the density of the body. $u(=k \cos \theta)$ and $v(=k \sin \theta)$ are the wavenumbers in $x$ and $y$ directions, $k\left(=\left(u^{2}+v^{2}\right)^{1 / 2}\right)$ is the magnitude of the wavenumber vector and $\theta=\arctan (v / u)$ shows its direction. The right hand sides of equation 3 depict the independent functions describing the shape of the source body and its density. Garcia-Abdeslem (1995) analyzed the radially averaged spectrum from gravity anomalies as an inverse problem and proposed an appropriate set of source parameters $m_{j}, j=1, M$ (i.e., $\left.a, b, t, h, \rho\right)$ such that $g(k ; m)$ explains the field data spectrum $d(k)$. He solved the inverse problem by calculating the minimization of a function defined by $Q(m)=\sum\left(d_{i}-g_{i}(m)\right)^{2}$, limits $i=1, N$. To estimate $m$ (the source parameters) a minimum of $Q(m)$ is calculated. Details of the iteration method are give in GarciaAbdeslem (1995, p. 1700). To estimate the confidence interval (error) for the dimensions of source body beneath the western continental margin and the intraplate Narmada-Tapti rifts, we have computed radially averaged numeric spectra for a cube
Table 1. Inversion of numeric spectrum from the example of a cube.

\begin{tabular}{lrrc}
\hline Parameters & True value & Initial value & Estimation \\
\hline$\rho\left(\mathrm{kg} / \mathrm{m}^{3}\right)$ & 1000 & 2000 & $934 \pm 24$ \\
$a(m)$ & 100 & 80 & $96 \pm 0.94$ \\
$b(m)$ & 100 & 120 & $94 \pm 0.92$ \\
$t(m)$ & 50 & 40 & $47 \pm 3.4$ \\
$h(m)$ & 30 & 40 & $28 \pm 0.2$ \\
\hline
\end{tabular}

(simplified shape of gravity high). Consider a cube with length $(a)=100 \mathrm{~m}$, width $(b)=100 \mathrm{~m}$, thickness $(t)=50 \mathrm{~m}, \rho=1000 \mathrm{~kg} / \mathrm{m}^{3}$ and located at a depth ( $h$, top surface) of $30 \mathrm{~m}$. First we computed the gravity effects $\Delta g(x, y)$ of cube in space domain and then 2-D power spectrum is computed by using a $2-\mathrm{D}$ discrete Fourier transform applied to $\Delta g(x, y)$. The calculated $2-\mathrm{D}$ power spectrum is simplified to a 1-D spectrum by taking natural logarithm of average value at each radial coordinate domain. The average value of $\Delta g(x, y)$ we obtained is a numerically equivalent of equation 3 . Both initial trial values of the model parameters and the results obtained after six iterations are listed in table 1 . As shown in figure 3 , the difference between the numeric (true value) and the synthetic (calculated value) spectra is also quite small. For example the estimated (modeled) length, width and depth (top surface) differ from the true values by about 4 to $8 \%$. The density differs by about $7 \%$. As a result, a realistic model shows that the estimated values for the mafic bodies beneath the western continental margin and the intraplate Narmada-Tapti rifts vary by about $8-10 \%$.

\section{Gravity models along the western continental margin rift}

\subsection{Two-dimensional model}

The positive Bouguer gravity anomaly along the western continental margin of India (from $72^{\circ} 20^{\prime}$ to $73^{\circ} 25^{\prime} \mathrm{E}$ and $18^{\circ} 14^{\prime}$ to $21^{\circ} \mathrm{N}$ ) with a high of +70 mgal near Bombay (Mumbai) (figure 2) extends in N-S direction for a limited distance in the offshore area (Kaila 1988). The eastern side of the Bouguer gravity high of +70 mgal near Bombay (Mumbai) has a steep gradient of $3 \mathrm{mgal} / \mathrm{km}$, and the eastern side of the gravity anomaly near Surat shows a gradient of $1.25 \mathrm{mgal} / \mathrm{km}$ (figure 2). The preliminary estimated maximum depths of the top of the mafic body (using equation 1) from these gradients are about $15.2 \mathrm{~km}$ and $15.6 \mathrm{~km}$, respectively. Figure 3 shows $2-\mathrm{D}$ gravity modeling along A-B near Bombay (Mumbai) (figure 2). 


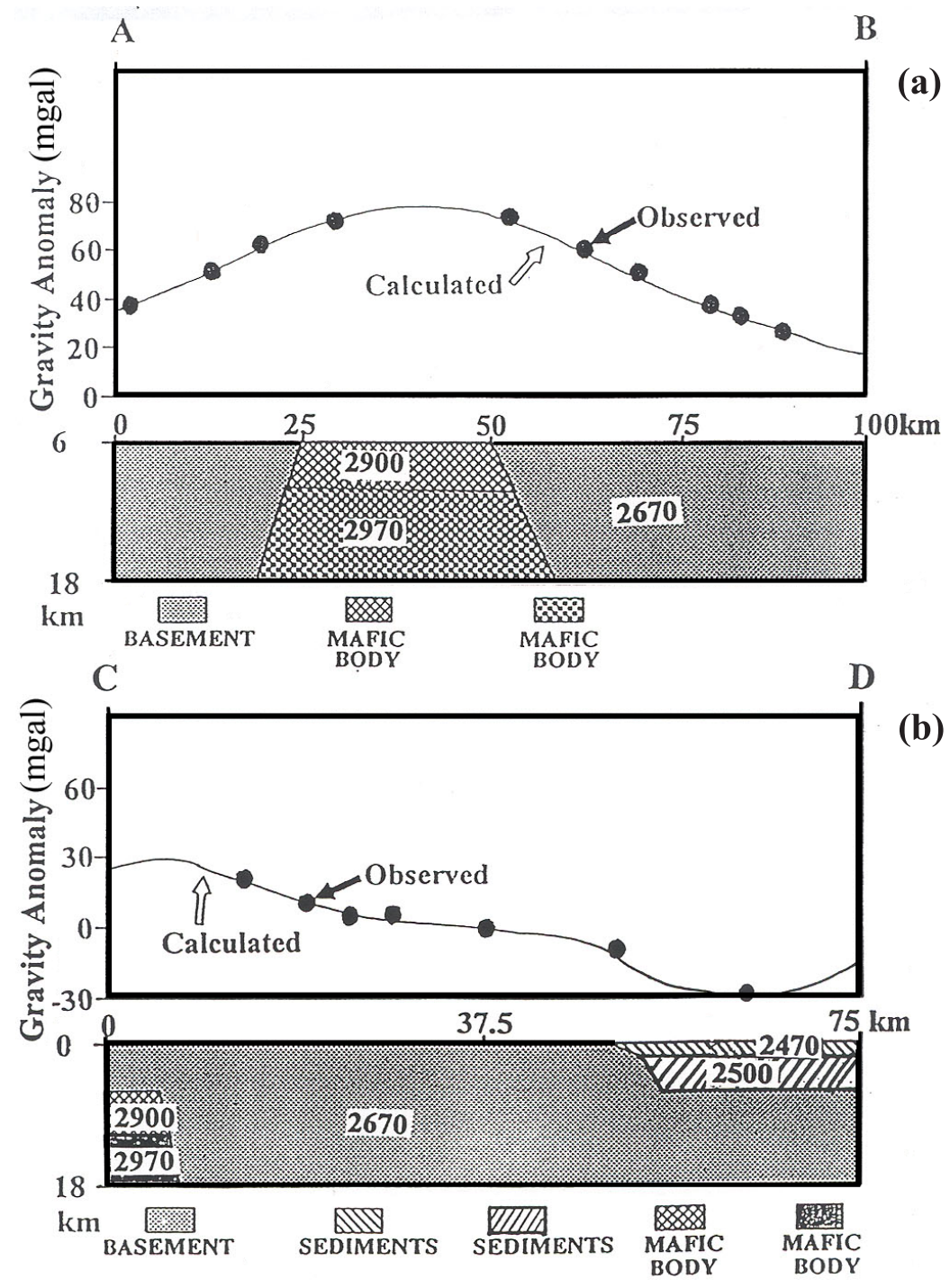

Figure 3. (a) A 2-D gravity model along A-B near Bombay (Mumbai) (see figure 2). The observed (solid circles) and theoretically calculated (line) anomalies match well when a (gabbroic type) mafic body with an average density of $2935 \mathrm{~kg} / \mathrm{m}^{3}$ is considered at a depth of $6.0 \pm 0.6 \mathrm{~km}$. The mafic body is $25 \pm 2.5 \mathrm{~km}$ wide at the top, and $40 \pm 4 \mathrm{~km}$ wide at the bottom. (b) A 2-D gravity model along C-D near Surat (see figure 2) indicates a density stratified mafic body emplaced at a depth of $6.0 \pm 0.6 \mathrm{~km}$. The horizontal dimensions of the mafic body are unknown because the gravity contours are open offshore.

The observed anomaly matches well with theoretically calculated gravity anomaly when a mafic body with an average density of $2935 \mathrm{~kg} / \mathrm{m}^{3}$ (density range: $2900-2970 \mathrm{~kg} / \mathrm{m}^{3}$ ) was assumed to have been emplaced at a depth of $6.0 \pm 0.6 \mathrm{~km}$ (hereon, all uncertainties are estimated at the $1 \sigma$ confidence level). This depth is consistent with the depth of last equilibration of Deccan magmas calculated from petrological modeling of chemical data $(2 \mathrm{kbar}$ or $7 \mathrm{~km}$, Sen 1995; Bhattacharji et al 1996). Estimated dimensions of this mafic body are approximately $25 \mathrm{~km}$ wide at the top and $40 \mathrm{~km}$ at the bottom. Interestingly, the total thickness of the Deccan basalts determined by deep seismic sounding (Kaila 1988) does not conform to the observed high of +30 mgal near Surat (along line C-D of fig- ure 2). However, the observed anomaly near Surat matches well with the theoretically calculated gravity anomaly if one assumes a zoned mafic body emplaced at a depth of $6.0 \pm 0.6 \mathrm{~km}$ (figure 3, line C-D of figure 2). The horizontal dimensions of this mafic body cannot be estimated, as the gravity anomaly contours are open in offshore area.

\subsection{Three-dimensional model}

The 3-D shapes of the mafic bodies responsible for the gravity highs of $+70 \mathrm{mgal}$ and $+30 \mathrm{mgal}$ along the western margin of India are determined on the basis of physical parameters such as width, length, thickness, depth, and density calculated from 2-D modeling (data given in table 2). The 
Table 2. Dimensions, depth and density of the mafic bodies along the western continental margin rift and along four DSS profiles (Kaila et al 1987, 1988; Kaila 1988) intersecting the Narmada-Tapti rift.

\begin{tabular}{|c|c|c|c|c|c|c|}
\hline Location & $\begin{array}{c}\text { Width } \\
\text { top } \\
(\mathrm{km})\end{array}$ & $\begin{array}{l}\text { Width } \\
\text { bottom } \\
(\mathrm{km})\end{array}$ & $\begin{array}{c}\text { Length } \\
\text { top } \\
(\mathrm{km})\end{array}$ & $\begin{array}{l}\text { Thickness } \\
\quad(\mathrm{km})\end{array}$ & $\begin{array}{c}\text { Depth } \\
(\mathrm{km})\end{array}$ & $\begin{array}{l}\text { Density } \\
\left(\mathrm{kg} / \mathrm{m}^{3}\right)\end{array}$ \\
\hline \multicolumn{7}{|c|}{ Mafic body along the western continental margin rift } \\
\hline Gravity High near & $25 \pm 2.5$ & $40 \pm 4$ & $300 \pm 30$ & $12.0 \pm 1.2$ & $6.0 \pm 0.6$ & $2900 \pm 290$ \\
\hline Bombay (Mumbai) & & & & & & $2970 \pm 297$ \\
\hline \multicolumn{7}{|c|}{ Mafic bodies on the northern side of the DSS profiles } \\
\hline Hirapur-Mandla & $6.5 \pm 0.5$ & $13.0 \pm 1.3$ & $20.0 \pm 2.0$ & $9.0 \pm 1.0$ & $6.0 \pm 0.5$ & $2970 \pm 297$ \\
\hline Khajuria Kalan- & $6.0 \pm 0.5$ & $9.0 \pm 0.9$ & $26.0 \pm 2.6$ & $13.0 \pm 1.3$ & $6.0 \pm 0.5$ & $2970 \pm 297$ \\
\hline \multicolumn{7}{|l|}{ Pulgaon } \\
\hline Ujjain-Mahan & $10.0 \pm 1.0$ & $10.0 \pm 1.0$ & $18.0 \pm 1.8$ & $13.0 \pm 1.3$ & $8.0 \pm 0.75$ & $2970+297$ \\
\hline Thuadara-Sindad & $26.0 \pm 2.5$ & $26.0 \pm 2.5$ & $23.0 \pm 2.3$ & $8.0 \pm 0.75$ & $6.0 \pm 0.5$ & $2900 \pm 290$ \\
\hline \multicolumn{7}{|c|}{ Mafic bodies on the southern side of the DSS profiles } \\
\hline Hirapur-Mandla & $6.5 \pm 0.5$ & $23.0 \pm 2.0$ & $26.0 \pm 2.6$ & $15.0 \pm 1.5$ & $6.0 \pm 0.5$ & $2970 \pm 297$ \\
\hline Khajuria Kalan- & $10.0 \pm 1.0$ & $38.0 \pm 3.5$ & $25.0 \pm 2.5$ & $14.0 \pm 1.4$ & $6.0 \pm 0.5$ & $2970 \pm 297$ \\
\hline \multicolumn{7}{|l|}{ Pulgaon } \\
\hline Ujain-Mahan & $20.0 \pm 2.0$ & $20.0 \pm 2.0$ & $28.0 \pm 2.8$ & $15.0 \pm 1.5$ & $8.0 \pm 0.75$ & $2970 \pm 297$ \\
\hline Thuadara-Sindad & $15.0 \pm 1.5$ & $15.0 \pm 1.5$ & $24.0 \pm 2.4$ & $12.0 \pm 1.2$ & $6.0 \pm 0.5$ & $2970 \pm 297$ \\
\hline
\end{tabular}

field gravity data were computed in a regular grid of $35 \mathrm{~km} \times 35 \mathrm{~km}$ in N-S and E-W directions, respectively. By using a 2-D discrete Fourier transform, a power spectrum was computed and after taking its natural logarithm a numerical equivalent of equation 3 (shown earlier) was obtained. For 3-D gravity modeling the thickness of the mafic body is taken as $12 \mathrm{~km}$ (as estimated from 2-D gravity modeling, table 2) at a depth of $6.0 \pm 0.6 \mathrm{~km}$ with an average density of $2935 \mathrm{~kg} / \mathrm{m}^{3}$ to start the initial calculations for the $+70 \mathrm{mgal}$ anomaly. Figure 4 shows the theoretically calculated gravity anomaly based on the 3-D shape of such a mafic body from the northwest direction from Surat to Bombay (Mumbai). The shape of the mafic body computed on the basis of 3-D gravity models indicates that a continuous mafic body is responsible for two gravity highs of +70 mgal and +30 mgal along the western continental margin of India instead of two separate and isolated mafic bodies proposed earlier by Negi et al (1992). The shape of this mafic body can be described as two connected ellipsoidal halves extending in the N-S direction. Both halves of ellipsoids are open at the western side (figure 4) as adequate gravity data from offshore region of the west coast of India are not available.

\section{Gravity models along the Narmada-Tapti rift}

Kaila et al (1987) and Kaila (1988) have obtained data along four DSS profiles, ranging from $200 \mathrm{~km}$ to $300 \mathrm{~km}$ in length over different parts of the intraplate Narmada-Tapti rift (figure 2). More recently, Verma and Banerjee (1992) studied the nature of the continental crust along the intraplate Narmada-Tapti rift using the DSS profiles and gravity anomaly data compiled under the CRUMANSONATA project of the Geological Survey of India (see also Nayak 1990). To study the relationship between the thickness of Deccan Traps and the depth of Moho, we have used the DSS profiles across the intraplate Narmada-Tapti rift (Kaila 1988) and have digitized the Bouguer gravity anomaly maps of Kaila (1988), Nayak (1990) and Verma and Banerjee (1992) except the residual gravity anomaly map over the Hirapur-Mandla profile of Verma and Banerjee (1992). This digitized gravity anomaly map and the DSS profiles of Kaila (1988) are then used in the 3-D gravity modeling.

\subsection{Two-dimensional model along Thuadara-Sindad profile}

The crustal depth section along the ThuadaraSindad DSS profile (figure 2) was mapped by Kaila et al (1989) and Kaila (1988). The thicknesses of the Deccan lavas along this profile vary from $0 \mathrm{~m}$ to $900 \mathrm{~m}$ overlying $1.9 \mathrm{~km}$ of Mesozoic sediments. The crustal section reveals five crustal blocks demarcated by deep-seated faults. In this area the depth of the Moho was found to vary from $40 \mathrm{~km}$ to $43 \mathrm{~km}$. Figure $5(\mathrm{~A})$ shows the observed gravity anomaly along this profile. The modeled gravity 


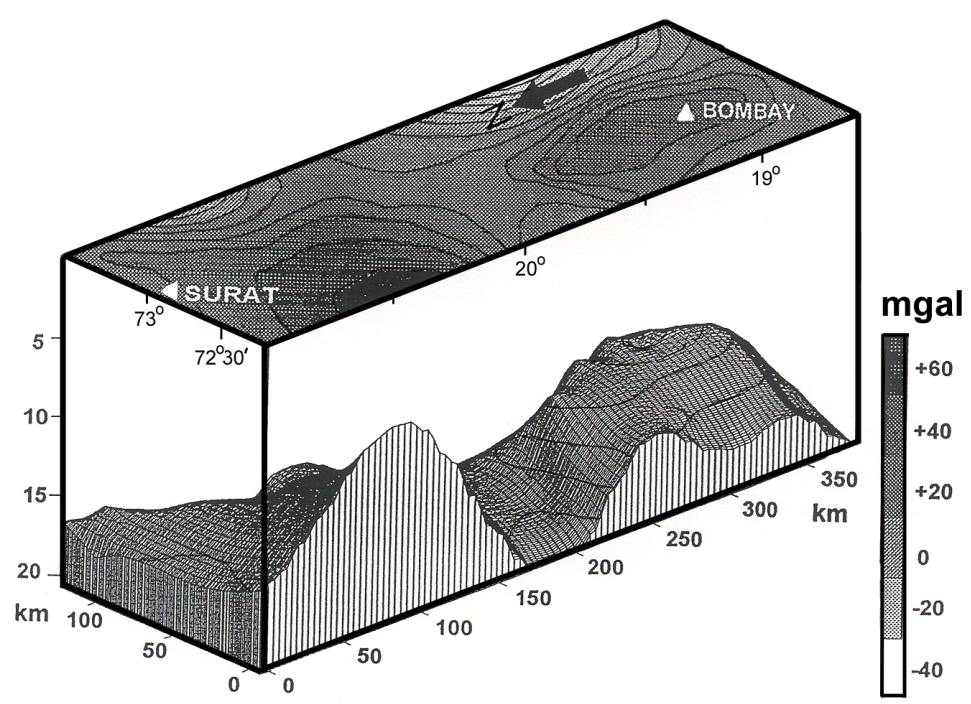

Figure 4. A 3-D gravity model of +70 mgal gravity high along the western continental margin of India. The irregularly distributed gravity data points are gridded in a grid of $35 \mathrm{~km} \times 35 \mathrm{~km}$ in N-S and E-W directions. The search method to locate the data points is octant and the gridding interpolation algorithm is minimum curvature. The orthographic view is from the northwest. The contoured field is the theoretically calculated gravity anomaly.

anomaly curve also matches well with the observed anomaly if the top surfaces of two mafic bodies are assumed to occur at a depth of $6.0 \pm 0.5 \mathrm{~km}$ (consistent with petrological modeling, Bhattacharji et al 1996; Sen 1995) in the crustal section, and the densities of these bodies are taken as $2900 \mathrm{~kg} / \mathrm{m}^{3}$ and $2970 \mathrm{~kg} / \mathrm{m}^{3}$, respectively. The modeled widths of the northern and southern gabbroic mafic bodies are $26 \pm 2.5 \mathrm{~km}$ and $15 \pm 1.5 \mathrm{~km}$, respectively.

\subsection{Two-dimensional model along Ujjain-Mahan profile}

A DSS profile on the central part of the NarmadaTapti rift from Ujjain to Mahan (figure 2) was carried out by Kaila (1988). In the northem part of this profile the Deccan Traps are $100 \mathrm{~m}$ thick. However, thickness of the Deccan Traps increases to $400 \mathrm{~m}$ in the southern side. Here, the Moho discontinuity is between $35 \mathrm{~km}$ and $40 \mathrm{~km}$. In this section two faults demarcating the Narmada-Tapti rift are also encountered. Figure 5(B) shows observed and calculated Bouguer gravity anomalies along the Ujjain-Mahan section. Here, the gravity anomaly shows a relative high of $50 \mathrm{mgal}$. The gravity anomaly effects produced by the Deccan volcanics and the Vindhyan sediments cannot explain the magnitude of the observed anomalies. In order to match observed and theoretical gravity anomalies, we have assumed two mafic bodies with density $2970 \mathrm{~kg} / \mathrm{m}^{3}$ and top surfaces at a depth of $8.0 \pm 0.75 \mathrm{~km}$. The calculated width and thickness of the mafic body near Ujjain are $10 \pm 1 \mathrm{~km}$ and $13 \pm 1.3 \mathrm{~km}$, respectively. The mafic body near
Mahan is estimated to have a width of $20 \pm 2 \mathrm{~km}$ and a thickness of $15 \pm 1.5 \mathrm{~km}$.

\subsection{Two-dimensional model along Khajuria Kalan-Pulgaon profile}

This DSS profile of Kaila et al (1989) reveals $100 \mathrm{~m}$ to $200 \mathrm{~m}$ thick Deccan lavas along the Khajuria Kalan-Pulgaon profile (figure 2). Here, the Moho is at depths between $34 \mathrm{~km}$ to $37 \mathrm{~km}$. Figure $5(\mathrm{C})$ shows the observed gravity anomaly along Khajuria Kalan-Pulgaon profile (Kaila and Rao 1985; Kaila 1988). The gravity anomaly shows a high of -20 mgal near Tapti river and a low of $-50 \mathrm{mgal}$ near Narmada river (figure 5C) giving a relative high of +30 mgal. The presence of two mafic bodies of density $2970 \mathrm{~kg} / \mathrm{m}^{3}$ in the crustal section are necessary to match calculated and observed gravity anomalies and approximate depths of the top surfaces of these assumed mafic bodies are at a depth of $6.0 \pm 0.5 \mathrm{~km}$. However, the dimensions (width and thickness) of the two bodies are different. The northern body is estimated to be $6.0 \pm 0.5$ to $9.0 \pm 0.9 \mathrm{~km}$ wide and $13 \pm 1.3 \mathrm{~km}$ thick, and the body near Pulgaon is estimated to be from $10 \pm 1 \mathrm{~km}$ to $38 \pm 3.5 \mathrm{~km}$ wide from top to bottom, and $14 \pm 1.4 \mathrm{~km}$ thick. The northern mafic body also seems to be connected below to a larger mafic body (figure 5C).

\subsection{Two-dimensional model along Hirapur-Mandla profile}

The easternmost DSS profile over Deccan volcanics from Hirapur to Mandla (figure 2) was carried 


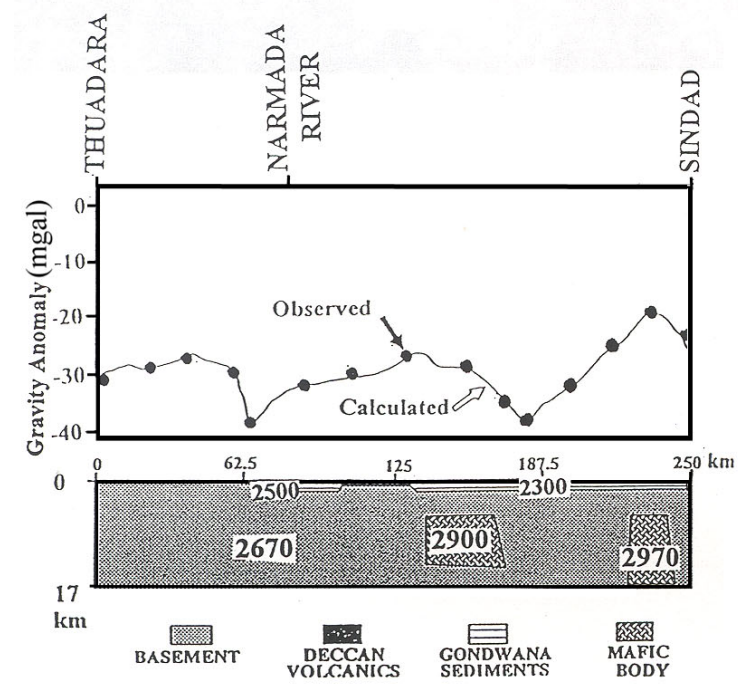

(A)

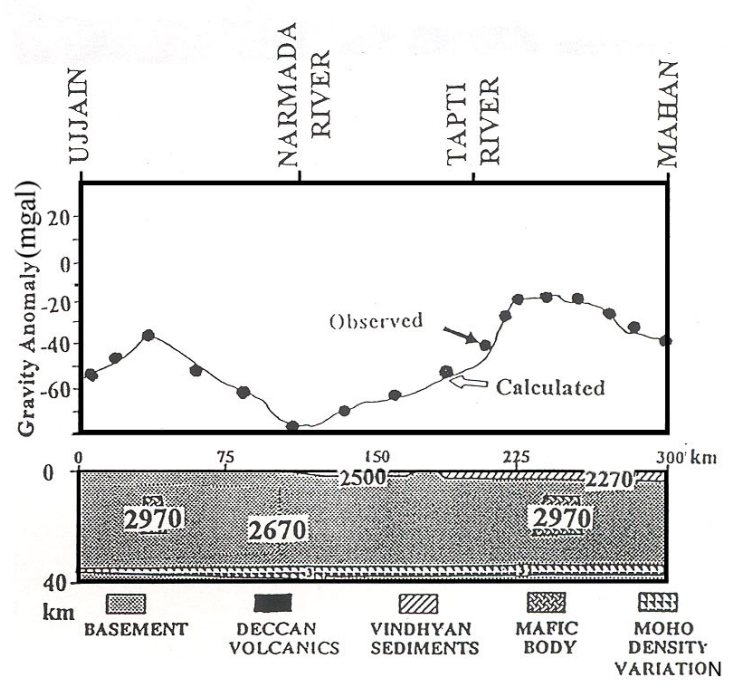

(B)

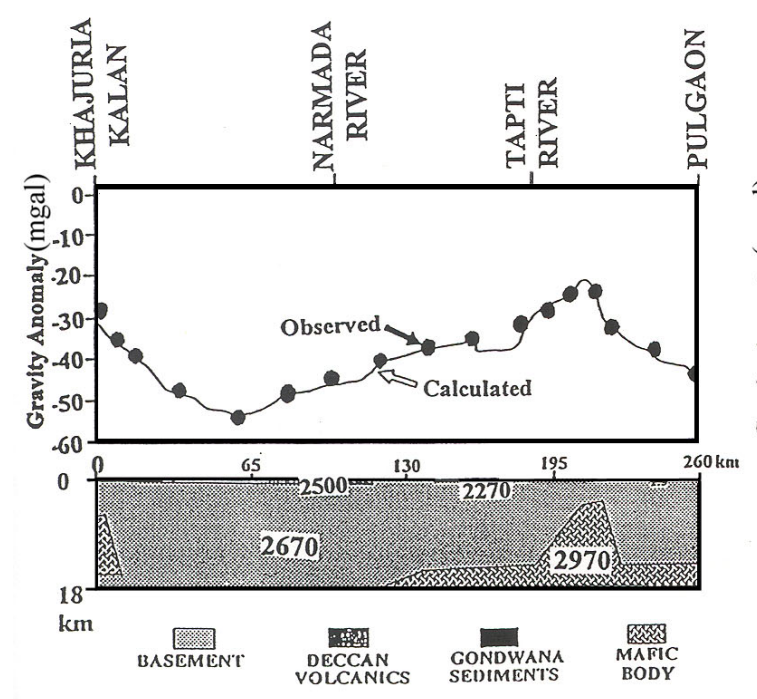

(C)

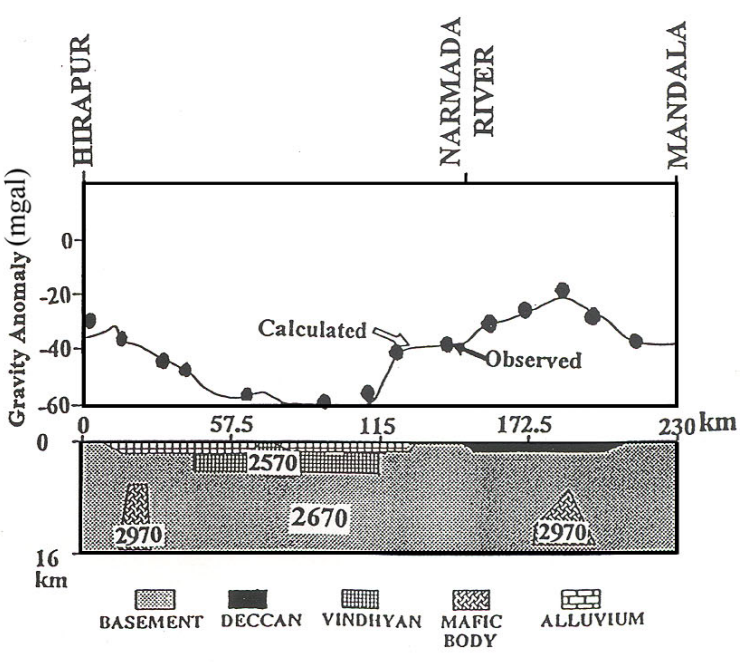

(D)

Figure 5. 2-D gravity models along (A) Thuadara-Sindad, (B) Ujjain-Mahan, (C) Khajuria Kalan-Pulgaon, and (D) Hirapur-Mandla profiles (Th-Si, Uj-Mn, Kh-Pu and Hi-Mn of figure 2) along the Narmada-Tapti rift of India. The observed (solid circles) and theoretically calculated (line) anomalies fit well when mafic bodies are considered at depths of $6.0 \pm 0.5 \mathrm{~km}(\mathrm{~A}, \mathrm{C}$ and $\mathrm{D})$ and $8.0 \pm 0.75 \mathrm{~km}(\mathrm{~B})$. See text for details.

out by Kaila et al (1987). Figure 5(D) shows the observed and calculated Bouguer gravity anomalies along the profile if two mafic bodies with density of $2970 \mathrm{~kg} / \mathrm{m}^{3}$ are assumed to be present in the upper crust. The tops of the modeled mafic bodies are estimated to be at a depth of $6.0 \pm 0.5 \mathrm{~km}$. The mafic body near Hirapur is estimated to be $6.5 \pm 0.5 \mathrm{~km}$ wide at the top and $13 \pm 1.3 \mathrm{~km}$ wide at the bottom, and $9 \pm 1 \mathrm{~km}$ thick. However, the body near Mandla is prismatic with a $23 \pm 2 \mathrm{~km}$ base and $15 \pm 1.5 \mathrm{~km}$ height.

\subsection{Three-dimensional shapes of mafic bodies along the Narmada-Tapti rift}

The 3-D shape of the mafic bodies responsible for the gravity highs in and across the Narmada-Tapti rift was computed using the methods given by Garcia-Abdeslem (1995), and equation 3. The constraints on the depth, thickness, width and density are taken from the 2-D gravity models of this study along the four DSS profiles (Kaila et al 1987, 1989; Kaila 1988). Table 2 lists the width (top, bottom), 
length, thickness, depth and densities of the mafic bodies (on the left and right hand sides) along four DSS profiles.

The average depth of the tops of mafic body responsible for a high of $40 \mathrm{mgal}$ is estimated to be $6.5 \pm 0.6 \mathrm{~km}$, which is also consistent with the results of petrological modeling of chemical data (Bhattacharji et al 1996; Sen 1995). Hence, for 3-D gravity modeling we have assumed a minimum depth of $6.5 \pm 0.6 \mathrm{~km}$ for each high of $40 \mathrm{mgal}$ along the Narmada-Tapti rift. We have shown earlier from 2-D gravity modeling along the NarmadaTapti rift that the density of mafic bodies responsible for the observed gravity highs is between 2900 and $2970 \mathrm{~kg} / \mathrm{m}^{3}$ (table 2). We have assumed an average density of $2961 \pm 294 \mathrm{~kg} / \mathrm{m}^{3}$ for 3-D gravity modeling of all mafic bodies along the intraplate Narmada-Tapti rift.

Figure 6 shows the modeled 3-D shapes of the mafic bodies between $73^{\circ} \mathrm{E}$ and $84^{\circ} \mathrm{E}$ longitudes and $20^{\circ} \mathrm{N}$ and $24^{\circ} \mathrm{N}$ latitudes. These mafic bodies are responsible for the gravity highs along the Narmada-Tapti rift. Note that all mafic bodies are perturbations from a larger mafic body at a depth of $25 \pm 2.5 \mathrm{~km}$. For this depth, the velocity data given by Kaila (1988) varies between $6.8 \mathrm{~km} / \mathrm{s}$ and $7.0 \mathrm{~km} / \mathrm{s}$ for which calculated densities should vary between $2900 \mathrm{~kg} / \mathrm{m}^{3}$ and $3000 \mathrm{~kg} / \mathrm{m}^{3}$. Hence, an average density of $2961 \pm 294 \mathrm{~kg} / \mathrm{m}^{3}$ for the mafic bodies beneath the intraplate NarmadaTapti rift considered here is consistent with the seismic velocity data.

\section{Discussion}

Tables 2 and 3 list the major differences in the gravity highs, and characteristics of modeled mafic bodies along the western continental margin and the Narmada-Tapti rifts of India. The maximum gravity high along the western coast is $+70 \mathrm{mgal}$ but in the Narmada-Tapti rift the average gravity high is $40 \mathrm{mgal}$ along the central horst (figure 1). The mafic body along the west coast (table 2) is $300 \pm 30 \mathrm{~km}$ long, $32.5 \pm 3.3 \mathrm{~km}$ wide and $12 \pm 1.2 \mathrm{~km}$ thick. In contrast, the average width, length and thickness of the mafic bodies along the NarmadaTapti rift (table 2) are $15.9 \pm 1.5 \mathrm{~km}, 23.8 \pm$ $2.4 \mathrm{~km}$ and $12.4 \pm 1.2 \mathrm{~km}$, respectively. However, the approximate depths of the tops and the densities of the mafic bodies are similar in both areas.

Rift systems and continental rifts elsewhere are generally associated with gravity highs. Gravity highs in passive continental margins, especially in the eastern United States are significantly lower than the gravity highs discussed in this paper. However, the gravity highs observed over the
Ethiopian Rift in eastern Africa show amplitude and wavelength (Girdler 1976) similar to those discussed in this paper. The Ethiopian Rift is a part of a triple-junction of the East African Rift System, and is related to the Afar hotspot (Bhattacharji and Koide 1975).

Morgan (1971) first postulated that the eruption of the Deccan volcanics occurred when the Indian plate was stationed on top of the Réunion hotspot. Later studies by Duncan and Pyle (1988), Richards et al (1989), Duncan (1990) and Duncan and Richards (1991) also indicate a close age and geochemical connections between the Réunion hotspot and the Deccan volcanics. Geophysical studies of the sea-floor of the eastern Arabian Sea and the Indian Ocean indicate the existence of a submarine ridge known as Chagos-Laccadive ridge (Cox 1988; White and McKenzie 1989; Singh 1998). This volcanic ridge shows a trend of younger ages from north to south and links the Deccan flood basalts to the Réunion hotspot (Duncan and Pyle 1988; White and McKenzie 1989) (figure 7A). The geochemical signatures (major, trace, rare earth and isotopic compositions of elements) of the Deccan volcanics and the Réunion hotspot also show many similarities (Dupuy and Dostal 1984).

The interactions of a hot mantle plume with the lithosphere have been considered responsible for the extrusion of flood basalts by many workers following Morgan's (1971) original proposal (Richards et al 1988, 1989; Campbell and Griffiths 1990). Sleep $(1990,1992)$ has proposed various models and explained lithospheric thinning due to secondary convection in the hot plume material ponded at the base of lithosphere. Recently, the oceanic volcanism and the bathymetric swell over a hotspot have been explained on the basis of density reduction created by melting above the hotspot (Morgan et al 1995). An alternate model has been proposed by Ihinger (1995) to expla en-echelon seamount segments along the Hawaiian-Emperor hotspot chain. According to this model, each seamount (gravity high) represents the surficial expression of individual mantle diapirs (plumelets). Various models have been proposed to explain the migration and geochemical structure of a plume and its interaction with the lithosphere. Unfortunately up to this date little is known about the size and shape of the magma bodies and rate of magma intrusion from the lower to the upper lithosphere over a hotspot. How and why the size, shape and the rate of migration of magma from hotspots vary from oceanic to continental lithosphere is still unknown and conjectural.

The kinematics of flow from a narrow plume through the asthenosphere have been numerically and geometrically investigated by Sleep (1990, 


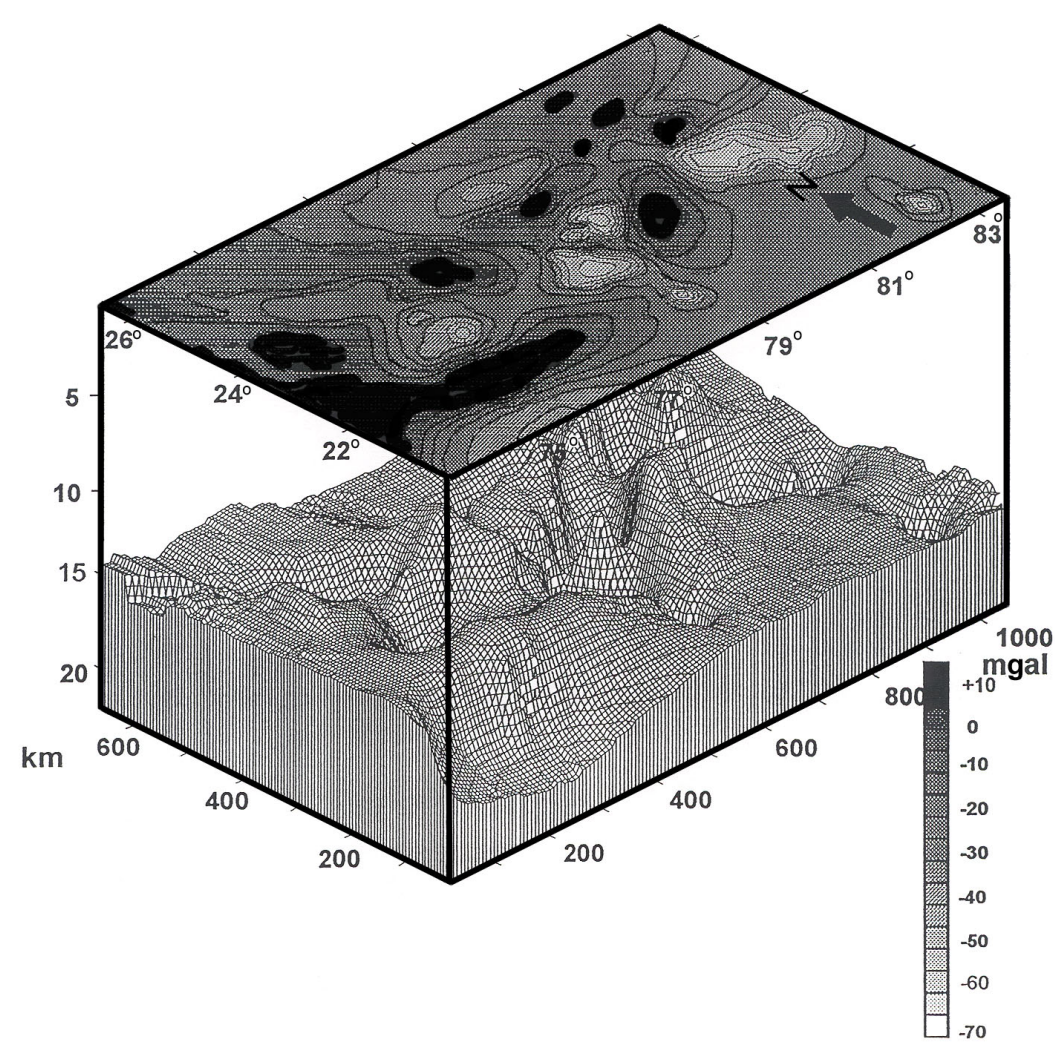

Figure 6. A 3-D gravity model showing shapes of mafic bodies along the Narmada-Tapti rift. The search method to locate the gravity data points is octant and the gridding interpolation method is minimum curvature. The orthographic view of the mafic bodies is from the southwest with a tilt of $30^{\circ}$. Note that the small mafic bodies are perturbations from a larger mafic body at depth.

1992), Richards et al (1988) and many others. The flow from a plume has been modeled in the form of radial motion interacting with the flow in the asthenosphere. These studies indicate that interaction of radial flows from the plume takes the shape of a parabola-like curve in the downflow direction. A similar model is used to explain the topography, geoid and heat flow anomalies associated with the Hawaiian hotspot (Sleep 1990, 1992). These studies show that the shape of the mafic bodies emplaced in the upper lithosphere when the Indian plate moved over the Réunion hotspot are roughly ellipsoidal (open ended) and are oriented in the N-S direction along the western continental margin of India. Gravity models in the area of the Deccan volcanics thus suggest that the shape of the magmatic bodies resulting from a stationary hotspot into a moving lithosphere can be convex upward and ellipsoidal. Figures 4 and 6 show the roughly ellipsoidal and convex upward mafic bodies along the western continental margin and intraplate rifts in the Indian lithosphere. Along the western continental margin, they were emplaced when the Indian plate moved rapidly northward over the Réunion hotspot (Richards et al 1989; White and McKenzie 1989; Duncan 1990; and figure 7A). The mafic bod- ies along the intraplate Narmada-Tapti rift were emplaced by rapid migration of the Deccan magma along an E-W oriented Precambrian lithospheric weak trend (Bhattacharji et al 1996).

Plate reconstructions and true polar wandering studies (Duncan 1990) indicate that shortly after the Deccan volcanic eruptions, Seychelles Bank and a small western portion of the Deccan volcanic province that was a part of western India drifted away from India and were joined to the African plate. The Narmada-Tapti rift is marked by the presence of Precambrian E-W to ENE-WSW lineaments and is a tectonic boundary between the southern peninsula and the northern foreland. The western continental margin is also characterized by the presence of N-S to NNWSSE oriented lineaments along which the rifting and breakup of India occurred. The presence of these Precambrian lineaments (lithospheric weak trends or paleo-rifts) and the alignment of mafic bodies along these lineaments seem to have played an important role in rifting along the NarmadaTapti rift, and rifting followed by breakup along the western continental margin. We have shown that small convex upward mafic bodies (gabbroic type, crystallized magma chambers) are emplaced at a 


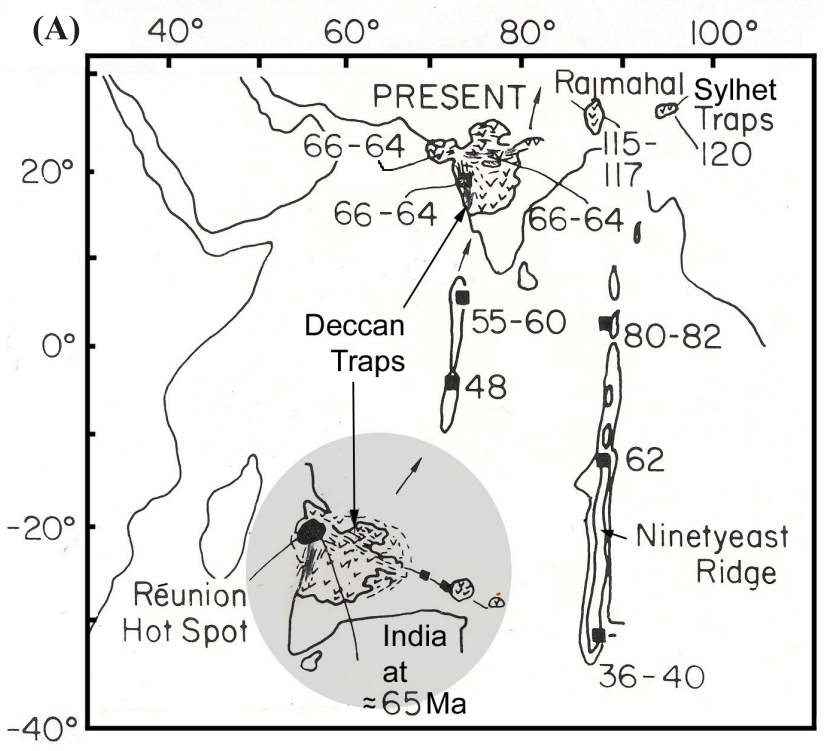

(B)

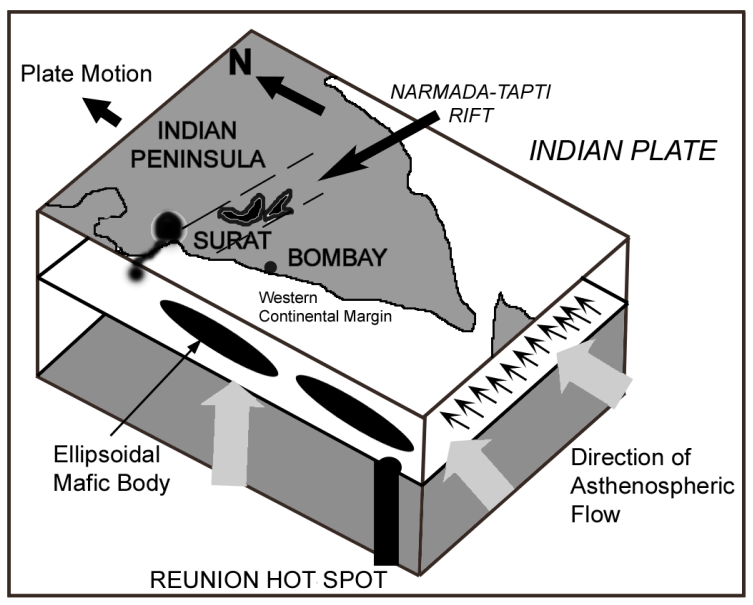

Figure 7. (A) A diagrammatic sketch showing impingement of the Réunion plume on Indian lithosphere at $\sim 65 \mathrm{Ma}$ (shaded area) and northward movement of Indian plate resulting in a northward age progression of rocks along the Réunion and Kerguelen (Ninetyeast ridge) hotspot tracks (Richards et al 1989; White and McKenzie 1989). The unit for the ages is Ma. (B) Cartoon showing emplacement of large, ellipsoidal mafic bodies along the western continental margin and smaller mafic bodies along the Narmada-Tapti rifts when the Indian plate moved over the Réunion hotspot. The model postulates that the emplacement of large ellipsoidal high density magmatic bodies would be dominant in the north-south direction due to rapid northward movement of the Indian plate and underplating, whereas, smaller magmatic bodies would be emplaced in the east-west direction along the Narmada-Tapti rift (modified after Cox 1988; Duncan and Pyle 1988).

depth of $\sim 6-8 \mathrm{~km}$ (table 2) along the Precambrian Narmada-Tapti lineament. These mafic bodies appear to be related to rifting along the NarmadaTapti lineaments (Bhattacharji et al 1996). Figure 7(B) illustrates possible emplacement of mafic bodies in the upper lithosphere paralleling the lin- eaments and rifts when the Indian plate was stationed over Réunion hotspot. The large dimensions (table 2) of N-S elongated mafic bodies aligned parallel to the western continental margin may be related to rifting and breakup of India from the Seychelles Bank (White and McKenzie 1989). Large mafic bodies along the western continental margin and smaller mafic bodies along the Narmada-Tapti rift at depths of $\sim 6-8 \mathrm{~km}$ appear to be the main source for the Deccan flood basalts. Petrological modeling based on olivineclinopyroxene-plagioclase saturated liquid compositions (Grove et al 1992), using geochemical data on feeder dikes and lowermost Deccan lava flows in the Narmada-Tapti valley and near Surat, also indicates that the Deccan magmas last equilibrated in feeder dikes and associated underlying multiple magma chambers at a depth of about $7 \mathrm{~km}$ along the Narmada-Tapti and western continental margin rifts (Bhattacharji et al 1996). The olivine tholeiite parents $(\mathrm{Mg} /(\mathrm{Mg}+\mathrm{Fe})=0.5$ to 0.58$)$ of these lower Deccan basalts possibly originated at an approximate depth of $18 \mathrm{~km}$ (Bhattacharji et al 1996), whereas, the Deccan primary magma originated from depths between 100 and $60 \mathrm{~km}$ by partial melting due to plume-asthenosphere interaction (Sen 1995). ${ }^{40} \mathrm{Ar} /{ }^{39} \mathrm{Ar}$ and $\mathrm{K}-\mathrm{Ar}$ age dating of the feeder dikes and associated lower Deccan lavas indicate that they were coeval and erupted at approximately $65 \mathrm{Ma}$ (Bhattacharji et al 1996). The geophysical model presented in this study is thus consistent with the geochemical, geochronological and petrological conclusions.

\section{Conclusion}

- The gravity anomalies discussed in this paper are not due to variations in the thickness of the Deccan volcanics; rather they are related to the high density bodies associated with continental margin and intraplate rifts.

- 2-D and 3-D gravity modeling in wavenumber domains reveal a high density, laterally elongated mafic body that parallels the western continental margin rift and several high density prolate perturbations (gabbroic type cupolas) rising from deeper level along the NarmadaTapti rift. The mafic bodies along the western continental margin are roughly ellipsoidal shaped, laterally elongated and larger in dimensions than those along the intraplate NarmadaTapti rift.

- The emplacement and orientation of the high density bodies in the upper lithosphere in the $\mathrm{N}-\mathrm{S}$ direction along the western continental margin rift appear to be related to the lineament reactivation and the western continental margin 
rifting, and eventual breakup of Seychelles Bank from India. While this process continued the intrusion of smaller convex upward mafic bodies along the intraplate Narmada-Tapti lineaments (rift) progressed with rift reactivation, normal faulting and crustal extension. The mafic bodies appearing as magma chambers along the western continental margin and the intraplate NarmadaTapti rifts in the upper lithosphere are considered as the major reservoirs for the Deccan flood basalt volcanism.

\section{Acknowledgements}

This paper is dedicated to Dr. L N Kailasam, Rtd. Director, Geophysical Division, Geological Survey of India for his pioneering work on Deccan Trap areas of peninsular India. The authors thank Professor John Chute of Lehman College of the City University of New York for his help with computer programming and for providing computer facilities. The authors also thank Late Dr. H Yoder of Geophysical Laboratory, Carnegie Institution of Washington, Professor W Sager and an anonymous reviewer from CUNY for valuable suggestions and comments during the preparation of this manuscript. The senior author thanks the Director, Librarian and Assistant Librarian of Geophysical Laboratory, Carnegie Institution of Washington D.C. for making library facilities available. Major part of the study was financially supported by a Faculty Research Grant of the City University of New York and NSF (International) grants to the senior author (SB). The authors thank three anonymous reviewers for their helpful suggestions for the improvement of this manuscript.

\section{References}

Bhattacharji S, Chatterjee N, Wampler J M, Nayak P N and Deshmukh S S 1996 Indian intraplate and continental margin rifting, lithospheric extension, and mantle upwelling in Deccan Flood Basalt volcanism near the K/T Boundary: Evidence from mafic dike swarms; J. Geol. 104 379-398

Bhattacharji S and Koide H 1975 Mechanistic model for triple junction fracture geometry; Nature 25/5 $21-24$

Bhattacharya C G and Subramanyam V 1986 Extension of the Narmada-Son lineament on the continental margin off Saurashtra, western India as obtained from magnetic measurements; Marine Geophys. Res. 8 329-344

Campbell I and Griffith R W 1990 Implications of mantle plume structure for the evolution of flood basalts; Earth Planet. Sci. Lett. 99 79-93

Cox K G 1988 Inaugural address. In: Deccan Flood Basalts; Geol. Soc. India Memoir 10 xv-xvii

Duncan R A 1990 The volcanic record of Réunion hotspot; Proc. ODP, Sci. Res. $1153-10$
Duncan R A and Pyle D G 1988 Rapid eruption of the Deccan flood basalts, Western India; Geol. Soc. India Memoir $101-10$

Duncan R A and Richards M A 1991 Hotspots, mantle plumes, flood basalts, and true polar wander; Rev. Geophys. 29 31-50

Dupuy C and Dostal J 1984 Trace element geochemistry of some continental tholeiites; Earth Planet. Sci. Lett. 67 61-69

Garcia-Abdeslem J 1995 Inversion of the power spectrum from gravity anomalies of prismatic bodies; Geophysics 60 1698-1703

Girdler R W 1976 The East African Rift System - Geophysical Aspect. In: Geodynamics: Progress and Prospects; (ed) C L Drake Amer. Geophys. Union, Washington D.C. $75-80$

Grove T L, Kinzler R J and Bryan W B 1992 Fractionation of mid-ocean ridge basalt (MORB). In: Mantle flow and melt generation at mid-oceanic ridges; Amer. Geophys. Union Geophys. Monograph 71 281-310

Ihinger P D 1995 Mantle flow beneath the Pacific plate: evidence from seamount segments in the Hawaiian-Emperor chain; Amer. J. Sci. 295 1035-1057

Kaila K L 1988 Mapping the thickness of Deccan trap flows in India from DSS studies and inferences about a hidden Mesozoic basin in Narmada-Tapti region. In: Deccan Flood Basalts; Geol. Soc. India Memoir 10 96-116

Kaila K L and Krishna V G 1992 Deep seismic sounding studies in India and major discoveries; Curr. Sci. 62 $117-154$

Kaila K L and Rao K 1985 Crustal structure along Khajuriakalan-Rahatgaon-Betul-Multai-Pulgaon profile across the Narmada lineament from deep seismic soundings. In: Deep seismic soundings and crustal tectonics; (eds) K L Kaila and $\mathrm{R} \mathrm{C}$ Tewari AEG Publ. $43-57$

Kaila K L, Krishna V G and Mall D M 1981 Crustal structure along Mehmadabad-Billimora profile in the Cambay basin, India from deep seismic soundings; Tectonophysics 76 99-130

Kaila K L, Murty P R K, Mall D M, Dixit M M and Sarkar D 1987 Deep seismic soundings along HirapurMandla profile, central India; Geophysics 89 339-404

Kaila K L, Rao J B P, Koteshwara Rao P, Madhava Rao N, Krishna V G and Sridhar A R 1989 DSS studies over Deccan Traps along the Thuadara-Sendhwa-Sindad profile across Narmada-Son lineament, India. In: Properties and processes of earth's lower crust; (eds) Mereu R F, Mueller S and Fountain D M Amer. Geophys. Union Geophys. Monograph 51 127-141

Kaila K L, Reddy P R, Dixit M M and Koteswara Rao P 1985 Crustal structure across the Narmada-Son lineament, Central India from deep seismic soundings; J. Geol. Soc. India 26 465-480

Kailasam L N, Murthy B O K and Chayanulu A Y S R 1972 Regional gravity studies of Deccan trap areas of Peninsular India; Curr. Sci. 41 40-47

Mishra D C 1977 Possible extension of the Narmada-Son lineament towards Murray ridge (Arabian Sea) and the eastern syn-taxial bend of the Himalayas; Earth Planet. Sci. Lett. 36 301-308

Mishra D C 1992 Mid continental gravity "high" of central India and Gondwana tectonics; Tectonophysics 212 153-161

Morgan W J 1971 Convection plumes in the lower mantle; Nature $23042-43$

Morgan J P, Morgan W J and Price E 1995 Hotspot melting generates both hotspot volcanism and a hotspot swell; J. Geophys. Res. 100 8045-8062 
National Geophysical Research Institute 1978 NGRI/GPH 1 to 5: Gravity maps of India, Scale 1:5,000,000; National Geophysical Research Institute, Hyderabad, India

Nayak P N 1990 Deep crustal configuration of central India; Geol. Surv. India, Special Publ. 28 67-98

Negi J G, Agrawal P K, Singh A P and Pandey O P 1992 Bombay gravity high and eruption of Deccan flood basalts (India) from a shallow secondary plume; Tectonophysics 206 341-350

Pant P R and others 1999 Significant inferences on deep crustal structure of Deccan Trap region from spectral analysis of Bouguer anomalies; J. Geol. Soc. India 53 315-328

Qureshy M N 1971 Relation of gravity to elevation, and rejuvenation of blocks in India; J. Geophys. Res. 76 545-557

Qureshy M N 1981 Gravity anomalies, isostasy and crust mantle relations in the Deccan Traps and the contiguous regions India; Geol. Soc. India Memoir 3 184-197

Radhakrishna M, Verma R K and Purushotham A K 2002 Lithospheric structure below the eastern Arabian Sea and adjoining West Coast of India based on integrated analysis of gravity and seismic data; Marine Geophys Res. 23(1) 25-42

Richards M A, Duncan R A and Courtillot V E 1989 Flood basalts and hotspot tracks: plume heads and tails; Science 246 103-107

Richards M A, Hager B H and Sleep N H 1988 Dynamically supported geoid highs over Hotspots: Observation and theory; J. Geophys. Res. 93 76990-77089

Sen G 1995 A simple petrologic model for the generation of Deccan Trap magmas; International Geol. Review $\mathbf{3 7}$ $825-850$

Sharma R and Bhattacharji S 1996 Three dimensional gravity modelling along intra-plate Narmada-Son and western margin rifts, India; Eos Trans. Amer. Geophys. Union 77 s74
Sharma P V 1986 Geophysical methods in geology; (Elsevier Science Publ.) 442pp

Singh A P 1998 3-D structure and geodynamic evolution of accreted igneous layer in the Narmada-Tapti region (India); J. Geodyn. 25(1-2) 129-141

Singh A P 2002 Impact of Deccan volcanism on deep crustal structure along western part of Indian mainland and adjoining Arabian Sea; Curr. Sci. 82 316-325

Singh A P and Meissner R 1995 Crustal configuration of the Narmada-Tapti region (India) from gravity studies; J. Geodyn. 20(2) 111-127

Sleep N H 1990 Hotspots and mantle plumes: Some phenomenology; J. Geophys. Res. 95 6715-6736

Sleep N H 1992 Hotspot volcanism and mantle plumes; Ann. Rev. Earth Planet. Sci. 20 19-43

Smith R A 1959 Some depth formulae for local magnetic and gravity anomalies; Geophys. Prospect. 7 55-63

Smith R A 1960 Some formulae for interpreting local gravity anomalies; Geophys. Prospect. 8 607-613

Takin M 1966 An interpretation of the positive gravity anomaly over Bombay on the west coast of India; $G e o-$ phys. J. Royal Astron. Soc. 11 527-537

Tewari B C, Murty X S N, Kumar P and Sridhar A R 2001 A tectonic model of the Narmada region; Curr. Sci. 80(7) $873-878$

Thakur N K, Nagarajan N and Joshi M S 1993 Estimation of the Bouguer gravity field over the peninsula using two dimensional filtering; Tectonophysics 225 543-550

U.S. Geological Survey 1997 National Earthquake Information Center, Earthquake Data Base on World Wide Web, http://wwwneic.cr.usgs.gov/cgi-bin

Verma R K and Banerjee P 1992 Nature of continental crust along the Narmada-Son lineament inferred from gravity and deep seismic sounding data; Tectonophysics 202 375-3979

White R S and McKenzie D P 1989 Magmatism at rift zones; the generation of volcanic continental margins and flood basalts; J. Geophys. Res. 94 7685-7729 